Esta revista forma parte del acervo de la Biblioteca Jurídica Virtual del Instituto de Investigaciones Jurídicas de la UNAM

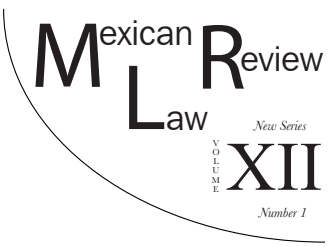

\title{
THE MEXICAN GENERAL LAW ON THE FORCED DISAPPEARANCE OF PERSONS, DISAPPEARANCES COMMITTED BY INDIVIDUALS AND THE NATIONAL MISSING PERSONS SYSTEM: HOW MANY STEPS FORWARD?
}

\author{
Salvador Leyva Morelos ZaragozA*
}

\begin{abstract}
In 2017, more than 40 years after some of the first documented cases of forced disappearance in Mexico, the General Law on the Forced Disappearance of Persons, Disappearances Committed by Individuals and the $\mathrm{Na}$ tional Missing Persons System was published. The approval and enactment of the General Law constitutes a step toward ensuring the free and full enjoyment of human rights of victims of forced disappearance and their next of kin, in accordance with the international human rights standards concerning forced disappearances established by international human rights treaties, the InterAmerican Court of Human Rights case law, the recommendations issued by the United Nations Committee and Working Group on Forced or Involuntary Disappearances, and the Inter-American Commission on Human Rights. The General Law introduces and modifies institutions, procedures and guidelines that contribute to ensuring the rights to justice, truth and reparation. However, the General Law does not fully comply with international human rights standards regarding military jurisdiction and criminal responsibility within the chain of command. Also, the proper and effective implementation of the General Law requires strong political will and sufficient material and human resources from the three levels of government. Otherwise, the General Law will simply be regarded as a piece of paper.
\end{abstract}

Keywords: Forced disappearances, International Human Rights Lau, Mexico, legislation.

* Member of the Special Monitoring Mechanism for Nicaragua (MESENI) launched by the Inter-American Commission on Human Rights. He earned his law degree from the Universidad Marista de Mérida, Yucatán, Mexico in 2014 and his LLM-Program in International Human Rights (cum laude) from the University of Notre Dame in 2018. Email: sleyvamz@gmail.com. 
Esta revista forma parte del acervo de la Biblioteca Jurídica Virtual del Instituto de Investigaciones Jurídicas de la UNAM

Resumen: En el 2017, más de 40 años después de algunos de los primeros casos documentados de desaparición forzada en México, se publicó la Ley General en Materia de Desaparición Forzada de Personas, Desaparición Cometida por Particulares y del Sistema Nacional de Búsqueda de Personas. La aprobación y la promulgación de la Ley General constituye un paso adelante para garantizar el disfrute libre y pleno de los derechos humanos de las víctimas de desaparición forzada y sus familiares, de conformidad con las normas internacionales de derechos humanos en material de desapariciones forzadas, así como con la jurisprudencia de la Corte Interamericana de Derechos Humanos, las recomendaciones emitidas por el Comité de las Naciones Unidas y el Grupo de Trabajo sobre Desapariciones Forzadas o Involuntarias, y la Comisión Interamericana de Derechos Humanos. La Ley General introduce y modifica instituciones, procedimientos y directrices que contribuyen a garantizar los derechos a la justicia, la verdad y la reparación. Sin embargo, la Ley General no está del todo conforme con los estándares internacionales de derechos humanos en lo atinente a la jurisdicción militar y la responsabilidad penal en la cadena de mando. Además, la implementación correcta y efectiva de la Ley General requiere una fuerte y politica voluntad politica, asi como de la asignación de suficientes recursos materiales y humanos por parte de los tres niveles de gobierno.

De lo contrario, la Ley General será solamente letra escrita.

Palabras clave: Desaparición forzada, Derecho Internacional de los Derechos Humanos, México, legislación.

\section{Table of Contents}

I. INTRODUCTION

II. International Human Rights Law Precedents

Concerning the Crime of Forced

Disappearance Applicable to Mexico

III. General Law on the Forced Disappearance of Persons, Disappearances CommitTed by Individuals

and the National Missing Persons System

IV. Typification of the Crime of Forced

Disappearance in Criminal Law....

V. Duty to Investigate the Grime

of Forced Disappearance.

1. Exclusion of Military Jurisdiction ........................................... 137

2. Special Prosecutor's Offices ("Fiscalías Especializadas") ........... 140

VI. The Right to Know the Whereabouts

or Fate of the Disappeared or Missing Persons.

1. Search Request Procedure 
Esta revista forma parte del acervo de la Biblioteca Jurídica Virtual del Instituto de Investigaciones Jurídicas de la UNAM

2. The National Missing Persons System

("Sistema Nacional de Búsqueda de Personas")

3. Registries and Data Banks

VII. The Rights of the Victims and their Next of Kin

1. Right to Full Reparation.

2. Special Declaration of Absence

("Declaración Especial de Ausencia")

VIII. Conclusion

\section{INTRODUCTION}

Latin America, and therefore Mexico, has been historically associated with the use of forced disappearances as a generalized State policy and terror tactics, but it is also the place where efficient responses to overcome such heinous crimes have emerged. ${ }^{1}$ The use of forced disappearance as a tool for political repression in Mexico can be traced back to the 1970s in the context of the so-called "Dirty War". ${ }^{2}$ While it is true that forced disappearances have been traditionally used as a strategy against subversive groups or "terrorists", it is also true that they are now being used in other contexts like those involving organized criminal groups or human mobility and human trafficking, which require a renewed scope of action. ${ }^{3}$ This renewed scope of action is the one that must be taken into account in Mexico's situation, where "[c]riminal cartels $[\ldots]$ often with the collusion of corrupt government officials, engage in

1 Ariel Dulitzky, Prologue, in La Desaparición Forzada en México: Una mirada desde los organismos del sistema de Naciones Unidas 7 [Forced disappearance in Mexico: From the perspective of United Nations bodies] (Office of the UN High Commissioner for Human Rights in Mexico ed. 2016).

2 Undeniable Atrocities: Confronting Crimes Against Humanity in Mexico, Open SoCIETy FOUNDATION 23-25 (2016), available at https://wrwrepensocietyfoundations.org/reports/undeniable-atrocities-confronting-crimes-against-humanity-mexico; Recomendación 26/2001, Casos sobre las quejas en materia de desapariciones forzadas ocurridas en la década de los 70 y principios de los 80, Comisión Nacional de Derechos Humanos (2001), available at http://wrwr.cndh.org.mx/ sites/all/doc/Recomendaciones/2001/Rec_2001_026.pdf; and Radilla Pacheco Case, 2009 InterAm Ct.H.R, (ser C) No. 209, at 132-137 (Nov. 23 2009). Also, the Special Prosecutors' Office for Social and Political Movements of the Past pointed at Rodolfo Reyes Crespo, a militant of the "Liga Comunista 23 de septiembre" as the first documented case of forced disappearance, occurred on 22 December 1973 in Guadalajara, Jalisco. Fiscalía Especial para Movimientos Sociales y Políticos del Pasado, Informe Histórico Presentado a la Sociedad Mexicana [Historical report for the Mexican Society], in Comité 68 Pro Libertades Democráticas, Genocidio Y DELITOS DE LESA HUMANIDAD: DOCUMENTOS FUNDAMENTALES 1968-2008, 516-554 (Carolina Verduzco Ileana Chávez José Revueltas ed. 2006).

3 Dulitzky, supra note 1, at 8-9. 
kidnappings for ransom, abductions for purposes of forced labor, and human trafficking related to the sex trade."4

Since its first judgment on the merits regarding the crime of the forced disappearance of Manfredo Velásquez Rodríguez, ${ }^{5}$ the Inter-American Court of Human Rights announced the States' obligation to "prevent, investigate and punish any violation of the rights recognized by the [American Convention on Human Rights] and, moreover, if possible, attempt to restore the right violated and provide compensation as warranted for damages resulting from the violation." 6

On October 12, 2017, the Mexican Chamber of Deputies approved a decree that created the General Law on the Forced Disappearance of Persons, Disappearances Committed by Individuals and the National Missing Persons System ("the General Law"). ${ }^{7}$ The Chamber of Deputies submitted the General Law to the President, who in turn enacted it on November 16, 2017. After being published in the "Diario Oficial de la Federación" [Federal Official Gazette], the General Law came into effect 60 days later, that is to say, January $18,2018 .^{8}$

The approval and enactment of the General Law constitutes a step toward ensuring the free and full enjoyment of human rights of victims of forced disappearance and their next of kin, according to the international human rights standards concerning forced disappearances. In particular, the Gen-

4 Undeniable Atrocities: Confronting Crimes against Humanity in Mexico, supra note 2, p. 40. See also, The Human Rights Situation in Mexico, Inter-Am C.H.R., OEA/Ser.L/V/ II.Doc.44/15, 41, 44, and 47 (2015).

5 Velásquez Rodríguez Case, 1988 Inter-Am. Ct.H.R., (ser C), 4, 147-148 (Jul. 29 1988).

6 Id. 166. See also G.A. Res 60/147. Basic Principles and Guidelines on the Right to a Remedy and Reparation for Victims of Gross Violations of International Human Rights Law and Serious Violations of International Humanitarian Law [hereinafter Basic Principles], Principle I, A/RES/60/147, (Mar. 21, 2006).

7 Dictámenes de las Comisiones Unidas de Justicia y de Derechos Humanos, con proyecto de decreto por el que se expide la Ley General en materia de Desaparición Forzada de Personas, Desaparición Cometida por Particulares y del Sistema Nacional de Búsqueda de Personas, y se reforman y derogan diversas disposiciones del Código Penal Federal y de la Ley General de Salud [Opinions of the United Commissions on Justice and Human Rights with a decree to enact the General Law on the Forced Disappearance of Persons, Disappearances Committed by Individuals and the National Missing Persons System, amending and repealing the Federal Criminal Code and the General Health Law] [Hereinafter Opinions with the General Law], Gaceta Parlamentaria, October 12, 2017 (Mex.).

8 Decreto por el que se expide la Ley General en Materia de Desaparición Forzada de Personas, Desaparición Cometida por Particulares y del Sistema Nacional de Búsqueda de Personas, y se reforman y derogan diversas disposiciones del Código Penal Federal y de la Ley General de Salud [Decree to enact the General Law on the Forced Disappearance of Persons, Disappearances Committed by Individuals and the National Missing Persons System, amending and repealing the Federal Criminal Code and the General Health Law] [Hereinafter General Law], Diario Oficial de la Federación [D.O.], November 12, 2017 (Mex.), Transitory Article 1. 
eral Law introduces and modifies institutions, procedures and guidelines that contribute to ensuring the rights to justice, truth and reparation. However, further amendments are needed for the General Law to fully comply with international human rights standards. Moreover, the correct and effective implementation of the General Law requires strong political will and sufficient material and human resources from the three levels of government.

In order to establish such an assessment, the General Law is evaluated under the scope of the established international obligations, especially but not restrictively, in the Inter-American Convention on the Forced Disappearance of Persons, ${ }^{9}$ the International Convention for the Protection of All Persons from Forced Disappearance,${ }^{10}$ the judgment of the Inter-American Court in the Radilla Pacheco Case, ${ }^{11}$ the recommendations issued to Mexico by the United Nations Committee and Working Group on Forced or Involuntary Disappearances, ${ }^{12}$ and the precedents of the Inter-American Commission on Human Rights. ${ }^{13}$

The second section briefly refers to the history of some international human rights instruments that regulate the crime of forced disappearance applicable to Mexico. The third section discusses the national legal and political context surrounding the approval and enactment of the General Law. Section four assesses Mexico's obligation to typify the crime of forced disappearance in criminal law. The fifth section discusses and analyzes the duty to investigate forced disappearances under the provisions of the General Law. The next section addresses several amendments made to laws and the creation or adjustment of the procedures and institutions used to ensure the right to know the whereabouts or fate of disappeared or missing persons. Finally, section seven refers to the rights of the victims of forced disappearance and their next of kin as recognized in the General Law.

9 Inter-American Convention on Forced Disappearance of Persons, June 9, 1994, available at http://wrww.oas.org/juridico/english/treaties/a-60.html.

10 International Convention for the Protection of All Persons from Forced Disappearance, Dec. 20, 2006, adopted by Resolution A/RES/61/177, Jan. 12, 2007, available at https:// treaties.un.org/doc/Publication/UNTS/Volume\%202716/v2716.pdf.

11 Radilla Pacheco Case, 2009 Inter-Am Ct.H.R, (ser C) No. 209, (Nov. 23 2009).

12 Commission on Human Rights, Report of the Working Group on Forced or Involuntary Disappearances, E/CN.4/1996/38 (Jan 15, 1996); General Assembly, Report of the Working Group on Forced or Involuntary Disappearances, Addendum, Mission to Mexico [Hereinafter Report of the Working Group-2011], A/HRC/19/58/Add.2 (Dec. 20, 2011); and Committee on Forced Disappearances, Concluding observations on the report submitted by Mexico under article 29, paragraph 1, of the Convention [Hereinafter Concluding observations], CED/C/MEX/CO/1, (Mar. 5, 2015).

13 The Human Rights Situation in Mexico, Inter-Am C.H.R., OEA/Ser.L/V/II.Doc. 44/15, (2015). 


\section{International Human Rights Law Precedents \\ Concerning the Grime of Forced Disappearance \\ Applicable to Mexico}

In 1993 the UN General Assembly adopted the Declaration on the Protection of All Persons from Forced Disappearance, proclaiming it as a "body of principles for all States", and urging them to make all efforts so that the Declaration becomes "generally known and respected." 14 Article 3 of the Declaration establishes "a broad obligation" to prevent and terminate acts of forced disappearance through the adoption and implementation of effective legislative, administrative, judicial, and other measures; the suitability of these measures will be reflected in their effectiveness "in preventing and, as appropriate, terminating acts of forced disappearance." $" 15$ Even when the Declaration did not provide a concrete definition of the term "forced disappearance", its elements were already present in the General Assembly's concern:

[...] in the sense that persons are arrested, detained or abducted against their will or otherwise deprived of their liberty by officials of different branches or levels of Government, or by organized groups or private individuals acting on behalf of, or with the support, direct or indirect, consent or acquiescence of the Government, followed by a refusal to disclose the fate or whereabouts of the persons concerned or a refusal to acknowledge the deprivation of their liberty, which places such persons outside the protection of the law $[\ldots]^{16}$

After the Declaration was made, the Inter-American Convention on Forced Disappearance of Persons (hereinafter "CFD") was adopted and defined "forced disappearance" 17 as:

$[T]$ he act of depriving a person or persons of his or their freedom, in whatever way, perpetrated by agents of the state or by persons or groups of persons acting with the authorization, support, or acquiescence of the state, followed by the absence of information or a refusal to acknowledge that deprivation of freedom or to give information on the whereabouts of that person, thereby impeding his or her recourse to the applicable legal remedies and procedural guarantees. ${ }^{18}$

14 Declaration on the Protection of All Persons from Forced Disappearance, Preamble, Feb. 12, 1993, A/RES/47/133, available at http://wrere.un.org/documents/ga/res/47/a47r133.htm.

15 Commission on Human Rights, Report of the Working Group on Forced or Involuntary Disappearances, 52-53, E/CN.4/1996/38 (Jan 15, 1996).

16 Declaration on the Protection of All Persons from Forced Disappearance, 3.

17 The terms "forced disappearance" and "enforced disappearance" are used indistinctly in this work.

18 See Inter-American Convention, Art. II. 
Mexico became a party to the CFD in 2002. ${ }^{19}$ The International Convention for the Protection of All Persons from Forced Disappearance (hereinafter "CED") was adopted by the United Nations General Assembly in 2006 and Mexico became a party in $2008 .{ }^{20}$ Article 2 of the CED defines forced disappearance as:

[...] the arrest, detention, abduction or any form of deprivation of liberty by agents of the State or by persons or group of persons acting with the authorization, support or acquiescence of the State, followed by a refusal to acknowledge the deprivation of liberty or by concealment of the fate or whereabouts of the disappeared person, which place such a person outside the protection of the law.

On November 23, 2009, the Inter-American Court declared Mexico responsible for the forced disappearance of Rosendo Radilla Pacheco at the hands of the security forces in 1974 within the context of the "Dirty War".21 Seven years later, on November 2016, the Inter-American Commission submitted to the Inter-American Court the Case 12.916, regarding the forced disappearance of Nitza Paola Alvarado Espinoza, José Ángel Alvarado Herrera, and Rocío Irene Alvarado Reyes "at the hands of State agents [...], since December 29, 2009. The fate or whereabouts of the three missing victims are still unknown." The Commission recalled that "[ $\mathrm{t}]$ his is the first case [brought before the Court] concerning forced disappearance in the context of the fight against drug trafficking and organized crime in Mexico."22

It is worth mentioning, that even when Mexico's international obligations on matters of forced disappearances came years before the Radilla Pacheco judgment, with the ratification of the abovementioned international treaties and conventions, among others, it was not until this judgment that Mexican authorities, starting with the Supreme Court of Justice, began paying attention to the fact that Inter-American Court judgments were mandatory. ${ }^{23}$

19 See, Decrees published on the Mexican Federal Official Gazette on January 18, 2002; February 27, 2002; May 6, 2002; and March 20, 2014; all available at http://legislacion.scjn.gob. $m x /$ Buscador/Paginas/wfOrdenamientoDetalle.aspx? $q=z m l k 7 / 89 A X 7 f K R T 4 O R 4 A d K v K S x U f a q K X d c T$ gYjK+29SOONvsI1RMTSsIm6r9p/ZM.

20 See Decrees published in the Mexican Federal Official Gazette on December 18, 2007, and June 22, 2012, Mexico City, Mexico, available at http://legislacion.scjn.gob.mx/Buscador/Pagi nas/wfOrdenamientoDetalle.aspx? $q=1 O y q D o f b F L G D A D 4 U X A / a L A d u f p M L L k F m a j 8 i P t C 8 g$ VNCbMKR tXOPeyf3e/3+bN2y.

21 Radilla Pacheco Case, supra note 11, 120-159 and Resolutive 3.

22 IACHR Takes Case involving Mexico to the Inter-American Court, IACHR, (Nov. 22, 2016), available at http://wrew.oas.org/en/iachr/media_center/PReleases/2016/173.asp.

23 See Derechos humanos contenidos en la Constitución y en los tratados internacionales. Constituyen el parámetro de control de regularidad constitucional, pero cuando en la Constitución haya una restricción expresa al ejericio de aquéllos, se debe estar a lo que establece el texto constitucional. Jurisprudencia emitida por la Corte Interamericana de Derechos Humanos. 
Esta revista forma parte del acervo de la Biblioteca Jurídica Virtual del Instituto de Investigaciones Jurídicas de la UNAM http://www juridicas unam mx/

https://biblio.juridicas.unam.mx/bjv

https://revistas.juridicas.unam.mx/

DOI: http://dx.doi.org/10.22201/iij.24485306e.2019.2.13641

Since then, the judiciary's criteria has evolved and developed on the issue; however, due to the scope limitation of this work, that development will not be specifically addressed here.

\author{
III. General Law on the Forced Disappearance \\ of Persons, Disappearances Committed by Individuals \\ and the National Missing Persons System
}

In 2015 the Mexican Constitution was amended to allow the Congress to enact general laws that establish, at least, the crimes and sanctions of kidnapping, forced disappearance or other kinds of illegal deprivation of freedom, human trafficking, torture and other cruel, inhuman or degrading treatment, as well as electoral crimes; a 180-day term was given to the Congress for it to issue the correspondent laws, a term which expired on January 6, 2016. ${ }^{24}$

A year later, the General Law on the Forced Disappearance of Persons, Disappearances Committed by Individuals and the National Missing Persons System was published. The International Committee of the Red Cross and the Office of the United Nations High Commissioner for Human Rights in Mexico recognized its importance. ${ }^{25}$

The enactment of the General Law responds to the intense activity and pressure from the civil society, ${ }^{26}$ and to the constant pronouncements issued by different international organizations like the Inter-American Commission on Human Rights ("the Commission"), the UN Committee on Forced Disap-

Es vinculante para los jueces mexicanos siempre que sea más favorable a la persona. Pleno de la Suprema Corte de Justicia [S.C.J.N.] [Supreme Court], Gaceta del Semanario Judicial de la Federación, Décima Época, tomo I, September 2013, Contradicción de Tesis 293/2011, Page 96 (Mex.).

24 Decreto por el que se reforma el artículo 73, fracción XXI, inciso a), de la Constitución Política de los Estados Unidos Mexicanos [Decree that amends Art. 73, Section XXI, Paragraph a) of the Mexican Constitution], Diario Oficial de la Federación [D.O.], July 10, 2015 (Mex.), Art. 73, Section XXI, paragraph b, and Second Transitory Article.

25 México: aprobación de ley general es un avance fundamental para fortalecer la búsqueda de decenas de miles de personas desaparecidas en el país, ICRC (2017), available at https://wrere. icrcorg/es/document/mexico-aprobacion-de-ley-general-es-un-avance-fundamental-para-fortalecer-la-busqueda$d e$, and La ONU-DH saluda la aprobación de la Ley general sobre desaparición de personas, OFIcina del Alto Comisionado de las Naciones Unidas para los Derechos Humanos en México (2017), available at http://wrere.hchrorg. $m x /$ index.php?option $=$ com_k2 Eview $=i t e m$ Eid $=1032: l a-o n u-d h$ saluda-la-aprobacion-de-la-ley-general-sobre-desaparicion-de-personasEItemid $=265$.

26 See Karla Tinoco, Exigen colectivos de Coahuila descongelar Ley Contra la Desaparición Forzada, VANGUARDIA (2016), available at http://wrerrevanguardia.com.mx/articulo/exigen-colectivos-de-coahuiladescongelar-ley-contra-la-desaparicion-forzada; and Gloria Leticia Díaz, Familiares de víctimas exigen que se apruebe Ley de Desaparición Forzada, Proceso (2017), available at http://wrerr.proceso.com. $m x / 478924 /$ familiares-victimas-exigen-se-apruebe-ley-desaparicion-forzada. 
pearances ("the Committee"), the UN General Assembly, and the UN Working Group on Forced or Involuntary Disappearances ("the Working Group"). ${ }^{27}$

\author{
IV. Typification of the Grime \\ of Forced Disappearance in Griminal Law
}

International human rights standards forbid Mexico from practicing, permitting, or tolerating the forced disappearance of persons under any circumstances, and bind it to punish those persons who commit or attempt to commit such crime, including their accomplices and accessories, and if applicable, their superiors; such obligations are to be met through any necessary measure. In that order, as a legislative measure, Mexico is bound to define forced disappearances as an offence under its criminal law, in accordance to international human rights standards, and shall establish appropriate penalties proportionate to the "extreme seriousness" of the crime. ${ }^{28}$

Now, even when forced disappearances were considered crimes in the Federal Criminal Code ${ }^{29}$ and in some state criminal codes, it was typified differently, leading to contradictions and obstacles in prosecuting those responsible for committing the crime. ${ }^{30}$ Regarding the Federal Criminal Law, the InterAmerican Court had already ordered Mexico to "adopt [...] the appropriate legislative reforms in order to make Article 215 A [...] compatible with the international standards in this subject" since "the elements of the crime shall guarantee the punishment of all the 'authors, accomplices, and accessories [...] whether agents of the State or 'people or groups of people that act with the authorization, support, or acquiescence of the State.",31

Besides the obligation to reform the typification of the crime of forced disappearance, the Working Group also recommended that it "should be in-

27 The Human Rights Situation in Mexico, supra note 13, Recommendation 9; Concluding observations Mexico, supra note 12, 16; General Assembly, Report of the Working Group on the Universal Periodic Review, 148.15, A/HRC/25/7 (Dec. 11, 2013); and Report of the Working Group-2011, supra note 12, 86.

28 Inter-American Convention on Forced Disappearance of Persons, Arts. I and III; International Convention for the Protection of All Persons from Forced Disappearance, Arts. 3, 4, 6, and 7; Goiburú et al. Case, 2006 Inter-Am. Ct.H.R., (ser C) No. 153, 92 (Sep. 22, 2006); Heliodoro-Portugal Case, 2008 Inter-Am. Ct.H.R., (ser. G) No. 186, 34, 107, and 112 (Aug. 12, 2008); Report of the Working Group-2011, supra note 12, 87; and Concluding observations Mexico, supra note 12, 20.

29 Código Penal Federal [Federal Criminal Code], as amended, Arts. 215-A, Diario Oficial de la Federación [D.O.], June 26, (Mex.).

30 Opinions with the General Law, supra note 7, 13-22. See also, Concluding observations Mexico, supra note 12, 19 and 20.

31 Radilla Pacheco Case, supra note 11, Operative Paragraph 11, and Radilla Pacheco Case, supra note 11, 320 . 
cluded in the criminal codes of all states and that a comprehensive law on forced or involuntary disappearances should be adopted without delay."32

In that sense, in order to overcome the obstacle presented by the multiple typifications of the crime of forced disappearance and considering that the effectivity of its investigation needs the regulation of such crime to be defined as an autonomous offence, ${ }^{33}$ the General Law now applies to the three Government levels (i.e. federal, state and municipal), ${ }^{34}$ is excluded under military jurisdiction, ${ }^{35}$ and defines the crime of forced disappearance as follows:

The crime of forced disappearance is committed when a public servant or the individual who, with authorization, support or acquiescence of a public servant, deprives a person of his or her liberty in any form, followed by the abstention or refusal to acknowledge such deprivation of liberty or to provide information related to the concerned person's fate or whereabouts ${ }^{36}$ (Unofficial translation).

The General Law establishes sanctions from 40 to 60 years of imprisonment and fines from 10,000 to 20,000 daily salaries to the person responsible for committing the crime of forced disappearance, and when perpetrated by a public servant, it requires removal from office and a ban on future service. ${ }^{37}$ The penalties may be subject to aggravating ${ }^{38}$ or mitigating ${ }^{39}$ circumstances

32 Report of the Working Group-2011, supra note 12, 86.

33 Radilla Pacheco Case, supra note 11, 144; Gomes Lund et al. ("Guerrilha do Araguaia") Case, 2010 Inter-Am. Ct.H.R. (ser. C) No. 219, 103 (Nov. 24, 2010); Gelman Case, 2011 InterAm. Ct.H.R. (ser. G) No. 221, 74 (Feb. 24, 2011); Torres Millacura et al. Case, 2011 Inter-Am. C.t.H.R. (ser. G) No. 229, 94 (Aug. 26, 201 1); and Concluding observations Mexico, supra note, 20.

34 See General Law, Arts. 3, 24, and 25.

35 See General Law, Art. 26.

36 See General Law, Art. 27.

37 Id. at Art. 30.

38 The penalties for the crime of forced disappearance provided for in this Law may be increased by up to half when: during or after the disappearance, the Disappeared Person dies due to any alteration in his or her health that is a consequence of the disappearance [...]; the disappeared person is a child or adolescent, a woman, [...] a person with a disability or an elderly person; the condition of migrant, afrodescendant, belonging to an indigenous people or community $[\ldots]$ the victim's gender identity or sexual orientation is the motivation for committing the crime; the person has been made to disappear as a result of his or her work as a human rights defender [... or] a journalist; the disappeared person is a member of a public security institution; the perpetrator or perpetrators have a family, friendship, employment, or trust relationship with the victim; or when the offenses are committed for the purpose of preventing the competent authorities from becoming aware of the commission of other offenses. Id., Art. 32 (Unofficial translation).

39 The penalties [...] may be reduced as follows: I. If the perpetrators or participants spontaneously release the victim within ten days of the disappearance [...]; II. If the perpetrators or participants provide effective information leading to the whereabouts of the disappeared person alive [...] III. If the perpetrator or participants provide effective information 
in accordance with international standards. ${ }^{40}$ The same sanctions apply to "the public servant or the individual who, with authorization, support or acquiescence of a public servant, conceals or refuses to provide information concerning the depravation of liberty or the whereabouts of a person, or conceals a detainee in any form $\left[\ldots . . . "{ }^{\prime 1}\right.$

On the other hand, civil society organizations pointed out that the General Law refuses to establish criminal responsibility for hierarchical superiors as the masterminds behind the crime. ${ }^{42}$ The lack of investigation of hierarchical superiors as the masterminds of the crime ("cadena de mando") prevents victims and society in general from knowing the circumstances of gross human rights violations committed by the military. It also prevents high rank officers and other civil public servants that request or allow military presence within their jurisdiction (i.e. municipalities or states), from being held accountable. ${ }^{43}$

The General Law provides for the responsibility of the hierarchical superiors "under the terms of the applicable criminal law". ${ }^{44}$ However, it does not fulfill the premises provided by the CED in which superior officials should also be held criminally responsible, and which in its concluding observations the Committee had already noted. ${ }^{45}$ In referring to the "terms of applicable criminal law", the General Law provides that hierarchical superiors may be

leading to the whereabouts of the body or human remains of the disappeared person [...]; IV. If the perpetrators or participants provide effective information that makes it possible to clarify the facts or identify those responsible [...]. Id., Art. 33 (Unofficial translation).

40 See Inter-American Convention on Forced Disappearance of Persons, Art. III, and International Convention for the Protection of All Persons from Forced Disappearance, Art. 7.2.

${ }^{41}$ General Law, Art. 28. (Unofficial translation.) The establishment of such crime complies, at least as a legislative measure, with the obligation to "prevent and sanction acts that hinder the conduct of an investigation." International Convention for the Protection of All Persons from Forced Disappearance, Art. 12.4

42 La aprobación de la Ley General en materia de Desaparición Forzada de Personas, Desaparición Cometida por Particulares y del Sistema Nacional de Búsqueda de Personas un paso positivo pero insuficiente para lograr la presentación con vida de las víctimas de desaparición forzada y el castigo a los culpables, Campaña Nacional contra la Desaparición FORZADA EN MÉXICO (2017), available at http://hastaencontrarlos.org/spip.php?article2139, and Arturo Angel, Registro inexistente, mandos sin sanción: 8 ausencias en la ley contra desaparición forzada, Animal Político (2017), available at http://wrwre.animalpolitico.com/2017/05/leydesaparicion-forzadal.

43 Ximena Suárez-Enríquez et al., La impunidad de las violaciones a derechos humanos cometidas por soldados en México, WOLA, Justicia OLvidada 29 (2017), available at https://wrere.wola.org/ wo-content/uploads/2017/11/WOLA_MILITARY-CRIMES_RPT_SPANISH.pdf. With regards to Inter-American standards to this regard, see, Oscar Parra Vera, La jurisprudencia de la Corte Interamericana respect a la lucha contra la impunidad: algunos avances y debates, REVISTA JURÍDICA DE LA UNIVERSIDAD DE PALERMO 19-20 (2012), available at https://wrerrepalermo.edu/derecho/revista_juridica/ pub-13/13JURIDICA_O1PARRAVERA.pdf.

44 See General Law, Art. 29.

45 International Convention for the Protection of All Persons from Forced Disappearance, Art. 6.b., and Concluding observations Mexico, supra note 12, 21 and 22. 
responsible for the crime of forced disappearance due to omission in cases when he or she had the legal duty to prevent it, as is the case of any public servant. ${ }^{46}$ However, it does not expressly include situations in which the hierarchical superiors may be prosecuted and sanctioned as intellectual authors, in accordance with international standards.

Additionally, the General Law establishes different penalties for the person responsible for failing to deliver to the competent authority or the victim's relatives a child born to the victim of forced disappearance during the period of captivity, and for the person who, with knowledge of the forced disappearance or disappearance committed by private individuals, retains or conceals the newborn. ${ }^{47}$ This typification complies with the recommendation issued by the Committee with this regard. ${ }^{48}$

According to Vélez Salas, distinguishing the crime of forced disappearance from other crimes related to the deprivation of liberty is crucial for the investigation and prosecution of forced disappearances, especially when the current situation in Mexico illustrates how many of these crimes, even when committed by private individuals, may entail the State's responsibility due to omission. $^{49}$

Moreover, the General Law also typifies the crime of disappearance committed by private individuals. Such crime is committed when private individuals (non-public servants) deprive a person of liberty for the purpose of concealing the victim, or his or her fate or whereabouts. Furthermore, the crime is punishable by imprisonment and a fine. ${ }^{50}$ The crime of disappearance committed by private individuals differs from that of forced disappearance "in that there is no certainty of the status of the perpetrator as a public servant, and until that status is determined, the charges are less severe [...]."51

The General Law also typifies other acts linked to forced disappearance, such as: concealing, disposing of, incinerating, burying, disintegrating, or destroying the remains or the corpse of a person, in order to conceal the commission of a crime; a public servant's preventing access to the authorities responsible for searching for missing persons, or obstructing said search; knowingly failing to provide information concerning the fate or whereabouts of a child born in captivity; falsifying, concealing or destroying documents proving the child's identity or using falsified documents of a child born in captivity. Public servants are subject to administrative responsibility when unjustifiably

\footnotetext{
46 Opinions with the General Law, supra note 7, 85.

47 See General Law, Arts. 31, 35 and 36.

48 Concluding observations Mexico, supra note 12, 45.

49 Alejandro Vélez Salas, Narrativas interdisciplinarias sobre desaparición de persona en México, CNDH 29-32 (2016), available at https://archivos.juridicas.unam.mx/wrew/bjv/libros/10/4985/4.pdf.

50 See General Law, Art. 34.

51 Opinions with the General Law, (unofficial translation), supra note 7, at 86.
} 
failing to comply with their obligations as established in the General Law as long as that failure does not constitute a crime. ${ }^{52}$

Additionally, the approved decree contemplates the amendment and repeal of several provisions in the Federal Criminal Code, as well as to eliminate the 60-year imprisonment sanction limit for the crime of forced disappearance and transfer it to the General Law. ${ }^{53}$ Finally, it adds an article to the Federal Criminal Code that punishes the person responsible for concealing, disposing of, incinerating, burying, disintegrating, or destroying, totally or partially, the remains or corpse of an unidentified person, without consent from the competent authority with imprisonment and a fine. ${ }^{54}$

The establishment of a single definition of the crime of forced disappearance in a general law that applies to the three levels of government constitutes a great step forward in prosecuting this crime. However, Mexico still has to fill the gap between what is written in its laws and their actual enforcement. It must not be forgotten that despite the fact the General Law applies nationwide, its enforcement will depend largely on state and municipal authorities (e.g. prosecutors, police officers, judges, magistrates, etc.) and on the local legal framework. In order to enforce these laws, material and human resources will be provided to the authorities in charge of investigating and prosecuting. On the other hand, even though the General Law applies nationwide, political will from states authorities is also needed and the mere publishing of the General Law cannot ensure that it will be forced.

Finally, further amendments to the General Law are needed in order to establish criminal responsibilities for hierarchical superiors as the masterminds of the crime of forced disappearance since, as it is now, it does not seem to be possible.

\section{Duty to Investigate the Grime of Forced Disappearance}

\section{Exclusion of Military furisdiction}

Article IX of the CFD establishes that the "[p]ersons alleged to be responsible for the acts constituting the offense of forced disappearance of persons may be tried only in the competent jurisdictions of ordinary law in each state,

52 See General Law, Arts. 37 to 43.

53 Opinions with the General Law, supra note 7, at Código Penal Federal, Arts. 25 and 215-A to 215-D.

54 Id. at Art. 280 Bis. The decree also includes several amendments to the Law on General Health related to the treatment of corpses and human remains. Id. at Ley General de Salud, Arts. 348, 350 Bis 3, 350 Bis 4, and 350 Bis 5 . 
to the exclusion of all other special jurisdictions, particularly military jurisdictions. [...]."

The first time the Inter-American Court addressed the issue of the matter of military jurisdiction in relation to human rights violations was in the Genie Lacayo Case in $1997 .{ }^{55}$ Since then, the Court has been constantly developing and modifying precedents on the matter. ${ }^{56}$

Moreover, in the 2009 Radilla Pacheco judgment, the Inter-American Court recalled its precedents in the sense that military criminal jurisdiction "shall have a restrictive and exceptional scope and be directed toward the protection of special juridical interests, related to the tasks characteristic of the military forces", namely crimes or offenses committed by active soldiers that threaten juridical rights of the military order itself. Therefore, it is not the competent jurisdiction for human rights violations, which correspond to the ordinary justice system. ${ }^{57}$ Therefore, it ordered Mexico to reform Article 57 of the Code of Military Justice, which established, in its relevants parts, that " $[\mathrm{t}]$ he crimes against military discipline are [...] those of the common or federal order, when $[\ldots]$ committed by soldiers during times of duty or based on the actions of the same."

Two years after the judgment in the Radilla Pacheco Case, the Supreme Court of Justice in Mexico, applying the conventionality control between international human rights norms and domestic law, found that Article 57, Section II, paragraph e) of the Code of Military Justice was not in compliance with international human rights law and, therefore, should not be applied. ${ }^{59}$

On ratifying the $\mathrm{CFD}$, the Mexican Government made express reservation to Article IX "inasmuch as the Political Constitution recognizes military jurisdiction when a member of the armed forces commits an illicit act while on duty," stating that:

[m] ilitary jurisdiction does not constitute a special jurisdiction in the sense of the Convention given that according to [...] the Mexican Constitution nobody

55 Genie Lacayo Case 1997 Inter-Am. Ct.H.R., (ser C) No. 30, 84 (Jan. 29, 1997).

56 With regards to the Inter-American Court's jurisprudence evolution, see Eduardo Ferrer Mac-Gregor, Las siete principales lineas jurisprudenciales de la Corte Interamericana de Derechos Humanos aplicable a la justicia penal, Vol. 59, REvisTa IIDH, 59-61 (2014).

57 Radilla Pacheco Case, supra note 11, 272-275. See also Economic and Social Council, Updated Set of principles for the protection and promotion of human rights through action to combat impunity [hereinafter Updated Set of principles], E/CN.4/2005/102/Add.1 Principle 1 (Feb. 8, 2005).

58 Code of Military Justice, cited in Radilla Pacheco Case, supra note 11, 271, footnote 272. Also, Sierra Leone, Peru, Brazil, Canada, Czech Republic, Italy, Australia, France, and Republic of Korea made similar recommendations within the context of the United Nations Universal Periodic Review. See Report of the Working Group on the Universal Periodic Review, supra note 27, 148.109.

59 Expediente Varios 912/10, Suprema Corte de Justicia de la Nación [S.C.J.N.] [Supreme Court], July 14, 201 1, 37-45 (Mex.) 
may be deprived of his life, liberty, property, possessions, or rights except as a result of a trial before previously established courts in which due process is observed in accordance with laws promulgated prior to the fact.

The Government also made a declarative interpretation in the terms that "[the Convention] shall apply to acts constituting the forced disappearance of persons ordered, executed, or committed after the entry into force of [the] Convention."

On July 11, 2014, Mexico withdrew its reservation with the express welcoming of the Inter-American Commission. ${ }^{61}$ Previously, on June 13, 2014, the executive branch published a decree amending several provisions of the Code of Military Justice, including Article 57, establishing the ordinary jurisdiction for cases where the victim concerned is a civilian. ${ }^{62}$ This amendment was assessed by the Inter-American Court through its compliance monitoring supervision attribution in the Radilla Pacheco Case and two other cases against Mexico. The Court declared that it "constitutes an important alignment of Mexican domestic law with conventional and international standards relating to military criminal jurisdiction," but that compliance was partial since the Military Code "still allows military jurisdiction for crimes committed by a military officer against another military officer." 63

A year after the amendment to Article 57, a federal court convicted a military officer of the crime of forced disappearance for the first time, imposing the penalty of 31 years in prison. The judge based his decision on the gross violation of the direct victim's rights to personal integrity, personal liberty and life, as well as the suffering of the victim's relatives and their right to the truth. ${ }^{64}$ Furthermore, by 2017, 545 members of the armed forces (502 from the Army, 32 from the Navy, and 11 from the Air Force) have been convicted or are being tried under the military jurisdiction, and sentenced to terms in military prison for committing or allegedly committing different crimes, including manslaughter, torture, forced disappearance, clandestine burial, and

60 Decrees published in the Mexican Federal Official Gazette on January 18, 2002, February 27, 2002 and May 6, 2002, supra note 18.

61 IACHR Welcomes Mexico's Withdrawal of Treaty Reservations, IACHR (2014), available at http://wrew.oas.org/en/iachr/media_center/PReleases/2014/076.asp, and Decree published in the Mexican Federal Official Gazette on March 20, 2014, supra note 19.

62 Decreto por el que se reforman, derogan y adicionan diversas disposiciones del Código de Justicia Militar, del Código Federal de Procedimientos Penales y de la Ley que Establece las Normas Mínimas sobre Readaptación Social de Sentenciados [Decree to amend, derogate, and add several provisions to the Code of Criminal Procedures for Military Justice and the Law on Social Readaptation for Convicts], Diario Oficial de la Federación [D.O.], 13 de junio de 2014.

63 Radilla Pacheco, Fernández Ortega et al., and Rosendo Cantú and other Cases, 2015 Inter-Am. Ct.H.R., Monitoring Compliance with Judgment, 20, 22-23, and Resolutive Paragraph 1 (Apr. 17, 2015) (Unofficial translation).

64 Nota Informativa 88/2015, PODER Judicial DE LA FEDERACiÓn (2015), available at http:// wrere.cjf.gob.mx/documentos/notasInformativas/docsNotasInformativas/2015/notaInformativa88.pdf. 
destruction of corpses; however, must of the military convicted or tried are from the lower military ranks. ${ }^{65}$

Removing cases concerning human rights violations from out of military jurisdiction has been a protracted struggle in Mexico. It has been more than seven years since the Radilla Pacheco case, and even when human rights violations, including forced disappearances, must now be tried in civil courts, the Military Penal Code needs to be further amended so that human rights violations, including forced disappearances, committed by military officers are also investigated and tried under civil jurisdiction.

If this is read bearing in mind that the General Law does not establish criminal responsibilities for hierarchical superiors as the masterminds of the crime of forced disappearance, the failure to amend the Military Penal Code proves the lack of political will to investigate, prosecute and convict military officers for the crime of forced disappearances. Finally, it seems that the draft legislation on internal security, which "would result in the normalization, regulation, and permanence of the armed forces in public security tasks" if approved, will constitute another obstacle to the prevailing impunity for agents of the armed forces involved in cases of human rights violations. ${ }^{66}$

\section{Special Prosecutor's Offices ("Fiscalias Especializadas")}

"Impunity arises from a failure by States to meet their obligations to investigate violations" and therefore States "shall undertake prompt, thorough, independent and impartial investigations [...] and take appropriate measures in respect of the perpetrators, particularly in the area of criminal justice, by ensuring that those responsible for serious crimes under international law are prosecuted, tried and duly punished." 67 The United Nations have recognized the "the importance of respecting and ensuring the right to the truth so as to contribute to ending impunity and to promote and protect human rights. $" 68$

Specifically, in the case of forced disappearances, the State is bound to ensure the right "to report the facts to the competent authorities, which shall examine the allegation promptly and impartially and, where necessary, undertake without delay a thorough and impartial investigation" even when there is no formal complaint. ${ }^{69}$

65 Zósimo Camacho, Cárceles militares: 545 efectivos caídos en desgracia, Contralínea.com.mx (2017), available at https://wwre.contralinea.com.mx/archivo-revista/2017/11/07/carceles-militares-545-efecti vos-caidos-desgracial.

66 IACHR Expresses Concern regarding Draft Law on Internal Security in Mexico, IACHR (2017), available at http://wrww.oas.org/en/iachr/media_center/PReleases/2017/200.asp.

67 Updated Set of principles, 19. See also, Basic Principles, Principle III, 4.

68 G.A. Resolution 68/165, Right to the truth, Preamble, 1, A/RES/68/165, (Jan. 21, 2014).

69 International Convention for the Protection of All Persons from Forced Disappearance, 
According to Open Societies, "official statistics on killings undercount the true toll: tens of thousands of disappearances, including those of migrants, remain unsolved and hundreds of clandestine and mass graves remain insufficiently investigated." ${ }^{70}$ The Committee has also expressed its concern regarding "the impunity surrounding the numerous cases of forced disappearance reported, which is evidenced by the near zero level of convictions for the offence." ${ }^{\prime 11}$ A Mexican representative stated before the Committee that "according to information available at the federal level, 313 officials had been indicted and 13 had been convicted to [2015]."

As obstacles to the investigation of the crime of forced disappearance in Mexico, the Committee pointed at the lack of prompt and immediate investigations of cases of forced disappearance and the classification of such crimes as other offences. Moreover, it recommended that the State undertake "a thorough and impartial investigation without delay, even if there has been no formal complaint, and that the perpetrators are prosecuted and, if found guilty, are punished in accordance with the grave nature of their acts" encouraging and facilitating "the involvement of the relatives of the disappeared person in the investigations, without conferring upon them any responsibility for providing the evidence necessary for the investigation" and guaranteeing "effective coordination and cooperation between all agencies involved in the investigation", which must ensure "that they have sufficient infrastructures and the technical, expert, financial and human resources to perform their functions expeditiously and effectively., ${ }^{, 73}$

Due to limitations of length, the present work focuses only on the specific regulations provided by the General Law regarding the investigation, prosecution and punishment of the crimes typified in the law, and not on general criminal procedural rules applicable for every criminal procedure.

In this sense, the General Law characterizes the crime of forced disappearance as permanent or continuous, ${ }^{74}$ is not subject to a statute of limitations and shall be prosecuted "motu propio" until the whereabouts of the victim have been determined or the victim's remains have been found. ${ }^{75} \mathrm{In}$

Arts. 12.1 and 12.2. See also, Radilla Pacheco Case, supra note 11, 143, and Concluding observations Mexico, supra note 12, 28.

70 Undeniable Atrocities: Confronting Crimes Against Humanity in Mexico, supra note 2, 12.

71 Concluding observations Mexico, supra note 12, 27.

72 Committee on Forced Disappearances, Summary record of the 120 th meeting, Preamble, 7 , CED/C/SR.120 (Feb. 6, 2015).

73 Concluding observations Mexico, supra note 12, 27, 28, 28.b), and 28.c).

74 These characteristics have been pointed out by the Inter-American Court of Human Rights since its first judgment of merits regarding forced disappearances to its most recent one. Velásquez Rodríguez Case, supra note 5, 158, and Gutiérrez Hernández et al Case, 2017 Inter-Am. Ct.H.R, (ser. C) No. 339, 124 (Aug. 24, 2017).

75 "The duty to investigate facts of this type continues as long as there is uncertainty about the fate of the person who has disappeared. Even in the hypothetical case that those individu- 
addition, it forbids the temporary suspension of the investigation under any circumstances, or any measure of impunity ${ }^{76}$ in accordance with Articles VII and VIII of the CFD.

It is important to point out that the Basic Principles and Guidelines on the Right to a Remedy and Reparation forbid the application of statutes of limitations where so contained in international obligations or provided for in treaties. ${ }^{77}$ However, even when neither the $\mathrm{CED}^{78}$ nor the $\mathrm{CFD}^{79}$ absolutely prohibit such statues of limitations, the General Law establishes that prosecution and sanction of the crime of forced disappearance are imprescriptible and cannot be subject to any statute of limitation of any kind. ${ }^{80}$

On the other hand, the Committee encouraged Mexico "to consider establishing $[. .$.$] a prosecution unit specializing in the investigation of cases of$ forced disappearances [...] to address this criminal scourge from a national and transnational perspective, supports the investigative function, and coordinates its work with other relevant agencies $[\ldots] .{ }^{.81}$

In response to this recommendation, the General Law binds both federal and state prosecution offices to establish Special Prosecutor's Offices (hereinafter "the Prosecutor's Office(s)") to investigate the crimes of forced disappearance and disappearance committed by private individuals. ${ }^{82}$

The federal Prosecutor's Office is responsible for receiving any criminal complaint related to the crimes typified in the General Law and has jurisdiction over the crimes established in the General Law when: a federal public servant is involved (as a perpetrator or a victim); jurisdiction is conferred to it by another law; there is a ruling issued by an international organization declaring the Mexican State as the responsible party; the Federal Prosecutor takes charge of an investigation from a state Prosecutor's Office; when the alleged perpetrator is a member of a criminal organization; or, when appropriate, the victims so request it. When none of the above circumstances applies, jurisdiction corresponds to state Prosecutor's Offices. ${ }^{83}$

ally responsible for crimes of this type cannot be legally punished under certain circumstances, the State is obligated to use the means at its disposal to inform the relatives of the fate of the victims and, if they have been killed, the location of their remains." Velásquez Rodríguez Case, supra note 5, 181.

76 The General Law, Arts. 13 to 15 and 17. In the same sense, Inter-American Convention on Forced Disappearance of Persons, Article X. Regarding the nature of restricting measures on rules of law justified by action to combat impunity, see Updated Set of principles, 22-28.

77 See Basic Principles, Principle IV 6.

78 International Convention for the Protection of All Persons from Forced Disappearance, Art. 8 .

79 Inter-American Convention on Forced Disappearance of Persons, Art. VII.

80 See General Law, Art. 14.

81 Concluding observations Mexico, supra note 12, 29.

82 See General Law, Arts. 68, 69, and 71.

83 Id. at Arts. 70 fraction I, and Arts. 24, and 25. 
The federal and the state Prosecutor's Offices should generate specific criteria and methodology to investigate and prosecute the crimes prescribed by the General Law, and liaise with other institutions (i.e. State SPOs, the National Missing Persons Commission and local commissions, the National Citizen Council, the federal and state Executive Committee for Victims Assistance, the Migrant External Support Mechanism and Crime Investigation Unit, ${ }^{84}$ police institutions, and other jurisdictional authorities) during the investigation of these crimes. Every authority from every government level, as well as individuals or organizations, are obliged to help and provide information to federal and state Prosecutor's Offices. ${ }^{85}$

Moreover, the Prosecutor's Offices must implement different measures to protect and assist the relatives searching their loved ones ${ }^{86}$ in accordance with Article 12.1 of the GED, which binds the State to take the appropriate steps in order to "to ensure that the complainant, witnesses, relatives of the disappeared person and their defense counsel, as well as persons participating in the investigation, are protected against all ill-treatment or intimidation as a consequence of the complaint or any evidence given."

More specifically, the federal Prosecutor's Office can apply to the "competent jurisdictional authorities" for authorization to perform exhumations in places where there are reasons to believe that a missing or disappeared person's remains might be buried. This Office is also in charge of locating the families of identified deceased persons so as to deliver the corpses or remains. Besides, it must facilitate the participation of family members in the investigation and periodically inform them of the progress made in the investigation. ${ }^{87}$

Finally, when the alleged perpetrator is a public servant, the federal Prosecution Office can apply to a judge to issue precautionary measures (e.g. suspension from office) in order to prevent his or her interference with the investigation $^{88}$ as requested by Article 12 of the CED, which binds the States to "ensure in particular that persons suspected of having committed an offence of forced disappearance are not in a position to influence the progress of an investigation by means of pressure or acts of intimidation or reprisal aimed at the complainant, witnesses, relatives of the disappeared person or their defense counsel, or at persons participating in the investigation." 89

84 The Committee recommended Mexico to "[...] redouble its efforts to prevent and investigate disappearance of migrants, to prosecute those responsible and to provide adequate protection for complainants, experts, witnesses and defense counsels." Concluding observations Mexico, supra note 12, 24.

85 General Law, Arts. 70, 73, and 75-77. To this regard, see International Convention for the Protection of All Persons from Forced Disappearance, Arts. 12.1 and 12.3.a).

86 See General Law, Arts. 153-157.

87 Id. at Art. 70 Sections XVII, XVIII and XX. / XVIII, XVII and XX.

88 Id. at Art. 72.

89 International Convention for the Protection of All Persons from Forced Disappearance, Art. 12.4. In the same order of ideas, see Concluding observations Mexico, supra note 12, 28.d). 
The effectiveness of the Prosecutor's Offices will largely depend on their funding, the training of their public servants, and the coordination between them, as well as with other institutions. If states fail to achieve even a single one of the minimum standards set out in the General Law, it could create "safe havens" for those responsible for committing the crime of forced disappearances and will impede their proper prosecution and conviction.

\author{
VI. The Right to Know the Whereabouts \\ or Fate of the Disappeared or Missing Persons
}

\title{
1. Search Request Procedure
}

In cases of forced disappearances "the family of the direct victim has an imprescriptible right to be informed of the fate and/or whereabouts of the disappeared person and, in the event of decease, that person's body must be returned to the family as soon as it has been identified, regardless of whether the perpetrators have been identified or prosecuted." 90

In accordance with the aforementioned principle, the General Law recognizes that "[i] rrespective of any legal proceedings, victims and their families have the imprescriptible right to know the truth about the circumstances in which violations took place and, in the event of death or disappearance, the victims' fate." "91 Such right involves the State's duty to "take all appropriate measures to search for, locate and release disappeared persons and, in the event of death, to locate, respect and return their remains." $" 92$

In that sense, the Working Group recommended that Mexico implement a "national search programme for missing persons with an immediate action protocol" and the corresponding guidelines, and that a "specific procedure for finding the disappeared person with the assistance of the relatives of victims should be established." "93 This responds to the fact that "in cases of forced disappearance, the prompt and immediate action of physical and judicial authorities through the order of the timely and necessary measures addressed to the determination of the whereabouts of the victim is essential." 94

90 Updated Set of principles, 34; International Convention for the Protection of All Persons from Forced Disappearance, Art. 24.2; and Radilla Pacheco Case, supra note 11, 180.

91 Updated Set of principles, 4.

92 International Convention for the Protection of All Persons from Forced Disappearance, Art. 24.3. See also, Concluding observations Mexico, supra note 12, 41.

93 Report of the Working Group-2011, supra note 12, 102 and 86. The IACHR also recommended to "[e]stablish mechanisms of immediate search for disappeared persons in the entire national territory." The Human Rights Situation in Mexico, supra note 13, Recommendation 10 .

94 Radilla Pacheco Case, supra note 1 1, 215, 222, and Osorio Rivera and Family members Case, 2013 Inter-Am. Ct.H.R., (ser G) No. 274, 178 (Nov. 26, 2013). 
The General Law creates the National Missing Persons Commission (hereinafter "the National Commission"), which will function as an administrative body that determines, executes and follows up on search actions for missing and disappeared persons. All authorities are obliged to collaborate with the National Commission and every state must create a Local Missing Persons Commission with analogous functions. ${ }^{95}$

More than fifty responsibilities were given to the National Commission regarding missing or disappeared persons, including: to design public policies; to request action from different public agencies and other government authorities; to develop and present reports on the matter as well as diagnostics of the situation; to request information from different authorities; to access any authority's information database platforms and registries without restrictions; to assist the victim's family members in the search of their loved ones and in obtaining reparations; to determine, execute and follow-up on missing or disappeared search actions; to collaborate with prosecutors in the investigation of forced disappearances and their perpetrators; and to coordinate with civil society and national, international, and foreign authorities in the search of missing or disappeared persons. ${ }^{96}$

Also, the National Commission and the local commissions shall be conformed of, at least, a Specialized Search Group ("Grupo Especializado de Búsqueda"), a Context Analysis Area ("Area de Análisis de Contexto"), Information Management and Processing Area ("Área de Gestión y Procesamiento de Información"), and the necessary administrative staff. ${ }^{97}$

The National Commission and local commissions will be in charge of performing the search request procedure, which starts with an investigation that continues until the whereabouts or fate of a missing or disappeared person are known and, if the case, the remains are identified. ${ }^{98}$

Once the National Commission or local commission acknowledges the disappearance of a person, it must immediately register the received information in the National Registry of Disappeared or Missing Persons. ${ }^{99}$ This registry must be constantly updated and the commission is required to provide and obtain information from the missing or disappeared person's family members. The National Commission must also start the search for the person and inform the Prosecutor's Office if there is the possibility that a crime was

95 See General Law, Arts. 50-52.

96 See General Law, Arts. 53, 54, 56, 134.

97 Id. at Arts. 58 and 65-67.

98 Id. at Arts. 2 fractions XIV and XXV, 79, 81, 83-86, 88, and 98.

99 The Law on National Registry of Disappeared or Missing Persons created the National Registry of Disappeared or Missing Persons. Ley del Registro Nacional de Datos de Personas Extraviadas o Desaparecidas [General Law on the National Registry of Missing or Disappeared Persons], Diario Oficial de la Federación [D.O.], April 17, 2012 (Mex.). 
committed, or if 72 hours have passed without news of the missing or disappeared person, or if the person is under 18 years of age. ${ }^{100}$

In order to find the person, the NGMP or the local commission must (with the prosecutors' cooperation if necessary) periodically and exhaustively consult the databases and registries of public and private health clinics, detention centers, forensic medical institutions, the National Registry of Unidentified Deceased Persons, public and private shelters and other social assistance institutions, cemeteries (or any other public or private place, where human remains are deposited), migrant stations, transportation terminals, and other registries and databases. If the person is found dead, the criminal investigation should continue in order to identify, locate and punish those responsible. ${ }^{101}$

The right of the direct victim's next of kin to know the fate and/or whereabouts of the disappeared person and, in the event of decease, to reclaim the disappeared person's remains has also been considered by doctrine and the Inter-American case law as one of the legal goods that should be protected by law. ${ }^{102}$ The General Law provides a decent framework to guarantee the abovementioned right; however, it should be pointed out that legally instituting the search request procedure, national and local commissions, and the registry will not succeed in its purposes without political will -or the corresponding resources.

\section{The National Missing Persons System ("Sistema Nacional de Búsqueda de Personas")}

The General Law creates a National Missing Persons System (hereinafter "the System"), whose purpose is to design and assess State resources in order to define the general bases, public policies and procedures among the authorities at all government levels to search for, locate and identify victims of forced disappearance and missing persons, as well as to prevent the crimes related to the General Law. In the exercise of its functions, the System will have various tools, including the National Registry of Disappeared or Missing Persons, the National Registry of Unidentified and Unclaimed Deceased Persons, the National Forensic Data Bank, the National Registry of Graves, the Administrative Detention Registry, the Standardized Search Protocol for Disappeared Persons and the Investigation of the Crime of Forced Disappearance, and the Amber Alert, among others. ${ }^{103}$

\footnotetext{
100 See General Law, Arts. 87, 89, 91, 92, and 96, Section VI.
}

101 Id. Arts. 94 and 96, Section V. See also, International Convention for the Protection of All Persons from Forced Disappearance, Arts. 12.1 and 12.3.b).

102 Juan Luis Modolell González, La Desaparición Forzada de Personas en el Sistema Interamericano de Derechos Humanos, in Desaparición Forzada de Personas, Análisis Comparado e InterNACIONAL 223-226 (Kai Ambos coord. 2009).

103 See General Law, Arts. 44 and 48. 
As mentioned before, the Working Group recommended that the "national search programme", rendered as the search request procedure, should be accompanied by an immediate action protocol. ${ }^{104}$ In 2015 the Standardized Search Protocol for Disappeared Persons and the Investigation of the Crime of Forced Disappearance ("Protocolo Homologado para la Búsqueda de Personas Desaparecidas y la Investigación del Delito de Desaparición Forzada") was approved and ratified by the National Security Council. ${ }^{105}$ The general objective of the protocol is to institute the principles and general procedures for the prosecutors, experts, and police forces in charge of the investigation of the crime of forced disappearance and thus make its investigation effective, locate the victims and sanction those responsible for the disappearance. It also establishes as a measure of non-recurrence. ${ }^{106}$

However, according to the General Law, the System is now in charge of issuing a Standardized Search Protocol for Disappeared and Missing Persons ("Protocolo Homologado para la Búsqueda de Personas Desaparecidas y No Localizadas"), which must include special procedures to search for and locate children and adolescents, migrants, or politically motivated disappearances. ${ }^{107}$

Moreover, the General Law establishes a National Citizen Council ("Consejo Nacional Ciudadano"), as a body made up of the victim's family members, human rights specialists, and representatives of civil society human rights organizations that will act in an advisory capacity to the System and the National Commission in terms of the search for missing and disappeared persons. ${ }^{108}$

\section{Registries and Data Banks}

Several recommendations have been issued to Mexico by international organizations, regarding the establishment and maintenance of information databases that can help with the search of missing or forced disappeared persons. ${ }^{109}$ In this sense, the General Law modifies the National Registry of Disappeared or Missing Persons and creates the National Registry of Unidentified Deceased Persons and the National Forensic Data Bank.

104 Report of the Working Group-2011, supra note 12, 102.

105 Acuerdos del Consejo Nacional de Seguridad Pública, aprobados en su Trigésima Octava Sesión Ordinaria [Agreements approved by the National Public Security Council], Diario Oficial de la Federación [D.O.] October 5, 2015 (Mex.).

106 Extracto del Protocolo Homologado para la Búsqueda de Personas Desaparecidas y la Investigación del Delito de Desaparición Forzada [Excerpt from the approved Protocol for the Search of Missing Persons and the Investigation of the Crime of Forced Disappearance], Diario Oficial de la Federación [D.O.], September 23, 2015 (Mex.).

107 See General Law, Art. 99.

108 General Law, supra note 12, Arts. 59 to 64.

109 The Human Rights Situation in Mexico, supra note 13, Recommendation 11, and Concluding observations Mexico, supra note 12, 18; Report of the Working Group-2011, supra note 12, 81 and 103 . 
First, the National Registry of Disappeared or Missing Persons aims to be an informational tool that organizes and concentrates information regarding missing or disappeared persons on a national database to help with the investigation, location and identification of missing or forced disappeared persons. ${ }^{110}$ Second, the National Registry of Unidentified and Unclaimed Deceased Persons, managed by the Office of the Federal Prosecutor and forming part of National Forensic Data Bank, contains updated forensic data on unidentified corpses or human remains, as well as information on the circumstances of their discovery. ${ }^{111}$ Finally, the National Forensic Data Bank is part of the System and concentrates and updates federal and state databases, in addition to other databases containing forensic and genetic information relevant to the search and identification of missing or disappeared persons. ${ }^{112}$

The three registries mentioned above are designed in such way that information is permanent, connected, and not duplicated, and allow the use of context analysis tools in order to determine crime patterns, modus operandi, criminological maps, and the structure and activities of organized criminal groups, among others. Furthermore, both the Federation and each state are obliged to, at least, have an Administrative Registry of Detentions and the National Registry of Graves. ${ }^{113}$

Apart from the criminal procedure and with all the tools established in the General Law for locating missing or disappeared persons, the search request procedure constitutes a big step forward in terms of the right to truth of the disappeared person's next of kin. However, the authorities in charge of each procedure and the institutions created must efficiently coordinate their efforts and have enough resources to perform their duties properly. If one of those institutions fails, it would affect the whole process.

\section{The Rights of the Victims And their NeXt of Kin}

\section{Right to Full Reparation}

It is worth recalling that the Working Group recommended that the definition of victim should be broad and "not linked to the establishment of the criminal liability and conviction of the accused." 114 In this sense, the General Law defines the victim's next of kin as:

110 See General Law on the National Registry of Missing or Disappeared Persons, Art. 2, and General Law, Arts. 102-110 and Second Transitory Article.

111 General Law, Arts. 111-113.

$112 I d$. at Arts. 4, fraction I, 119 and 124.

113 Id. at Arts. 131, Sections I and II, and Arts. 132 and 133. This systemization will contribute the establishment and implementation of "policies relating to prevention, eradication, investigations, penalties and reparation," as recommended by the Working Group. Report of the Working Group-2011, supra note 12, 81.

114 Report of the Working Group-2011, supra note 12, 109. 
[ $\mathrm{t}$ ]hose who, under the terms of the applicable legislation, are related to the disappeared or missing person by consanguinity or affinity, in a direct ascending or descending line without degree limitation; in transversal line up to the fourth degree; the spouse, concubine or, as the case may be, those who are subject to regime of a domestic partnership or similar legal constructs. Likewise, persons who are economically dependent on the disappeared or missing person and can demonstrate it before the competent authorities; [...] (Unofficial translation). ${ }^{115}$

That said, "[a]ny human rights violation gives rise to a right to reparation on the part of the victim or his or her beneficiaries, implying a duty on the part of the State to make reparation and the possibility for the victim to seek redress from the perpetrator." 116 In cases of forced disappearance, the duty to repair is understood in the sense that "[1] egislation must provide that reparation should be proportional to the gravity of the violation and suffering of the victim and his or her family. Provision should be made for restitution, as and when possible, as well as for medical and psychosocial care, satisfaction, compensation and guarantees of non-repetition." 117

The GED also binds States, and therefore Mexico, to "ensure in its legal system that the victims of forced disappearance have the right to obtain reparation and prompt, fair and adequate compensation" that "covers material and moral damages and, where appropriate, other forms of reparation such as: [r] estitution; [r] ehabilitation; [s]atisfaction, including restoration of dignity and reputation; [g] uarantees of non-repetition." $" 118$

Since 2013, the rights of the victims of federal crimes or human rights violations is specifically regulated in the General Law for Victims, which binds the three levels of government to ensure victims' protection, and grant them restitution, rehabilitation, compensation, satisfaction and guarantees of non-repetition in its individual, collective, material, moral, and symbolic dimensions, considering the seriousness and magnitude of the violation and its specific characteristics. ${ }^{119}$ Due to limitations of length, the rights, institutions and procedures established in the General Law for Victims are not addressed in the present work. However, it is worth mentioning that the Committee pointed out that further efforts are needed to achieve its implementation. ${ }^{120}$

115 See General Law, Art. 4, Section IX.

116 Basic Principles, 31.

117 Report of the Working Group-2011, supra note 12, 108.

118 International Convention for the Protection of All Persons from Forced Disappearance, Arts. 24.4 and 24.5. For definitions of restitution, rehabilitation, compensation, satisfaction and guarantees of non-repetition, and what they include, see Basic Principles, 19-22.

119 Decreto por el que se expide la Ley General de Víctimas [Decree for the General Law for Victims], Diario Oficial de la Federación [D.O.], January 9, 2013, Art. 1 (Méx.).

120 Concluding observations Mexico, supra note 12, 38 and 39. 
However, the General Law stresses that victims of forced disappearance and the other crimes established therein have the imprescriptible right to full reparation, under the terms of the abovementioned General Law for Victims. ${ }^{121}$ The General Law establishes that full reparation for victims of the crimes established in the law include, in addition to the provisions of the General Law for Victims, the Inter-American Court of Human Rights case law and International Law, measures of satisfaction (i.e. memorial monuments; a public apology from the State, the perpetrators of the crime and other persons involved; and the recovery of community meeting places; the recovery of the honor and memory of the disappeared person; and the recovery of practices and traditions that might have been lost due to a victimizing event); and guarantees of non-recurrence (e.g. temporary or definitive suspension of the public servants prosecuted or punished). ${ }^{122}$

Now, the General Law also recognizes the specific rights of both the direct victims of forced disappearance or disappearance committed by individuals, ${ }^{123}$ and their family members. ${ }^{124}$ The General Law also provides for preventive measures, ${ }^{125}$ notwithstanding the provisions of the General Law for the Social Prevention of Violence and Delinquency and the General Law of the National Public Security System, including the installation of security cameras in every official facility where there might be a person deprived of his or her freedom; the administration of statistical databases that include impact of the crimes, the circumstances, vulnerability groups, modus operandi, territorial delimitation, high risk routes and areas where the probability of such crimes are high; information campaigns; training for public servants officers on matters of human rights and forced disappearances.

The latter seems to be in accordance with international human rights standards. ${ }^{126}$ However, as stated in previous chapters, the effective implementation of the General Law depends on further actions and political will.

121 See General Law, Art. 150.

122 Id. at Art. 151. In this sense, see Principle 36.a) of the Updated Set of principles.

123 See General Law, Arts .137 and 149.

124 Id. at Arts. 138-141.

125 Id. at Arts. 158-159, 160, 161, 167, 168, 172 and 173.

126 The CFD binds States to "ensure that the training of public law-enforcement personnel or officials includes the necessary education on the offense of forced disappearance of persons." Inter-American Convention on Forced Disappearance of Persons, Art. VIII. The CED also obliges States to "ensure that the training of law enforcement personnel, civil or military, medical personnel, public officials and other persons who may be involved in the custody or treatment of any person deprived of liberty includes the necessary education and information regarding the relevant provisions of [the CED]." International Convention for the Protection of All Persons from Forced Disappearance, Art. 23.1. See also Concluding observations Mexico, supra note 12, 37. 


\section{Special Declaration of Absence ("Declaración Especial de Ausencia")}

Article 24.6 of the CED establishes the State obligation to "take the appropriate steps with regard to the legal situation of the disappeared persons whose fate has not been clarified, and that of their relatives, in fields such as social welfare, financial matters, family law and property rights," regardless of its duty to clarify the fate of the disappeared person.

In this sense, the Committee recommended Mexico to "take the necessary steps to ensure that legislation [...] establishes a procedure for obtaining a declaration of absence due to forced disappearance in order to deal appropriately with the legal situation of disappeared persons whose fate has not been clarified and that of their families." 127

Accordingly, the General Law states that family members may ask the competent jurisdictional civil authorities for a special declaration of absence of the victim three months after the authority acknowledges having filed a report on the disappearance of a person, and the authority has six months to decide on said declaration. ${ }^{128}$ This declaration has only civil effects and therefore does not produce the effects of criminal statute of limitations or evidence in criminal proceedings, and neither does it stops the search of the disappeared person. ${ }^{129}$

The purpose of the declaration of absence is to recognize and protect legal personality of the disappeared person and to grant the proper measures to ensure the broadest possible protection to the family members of the disappeared person. ${ }^{130}$

The establishment of special declaration of absence allows the next of kin of the disappeared or missing person to safeguard their rights as long as his or her whereabouts are unknown. However, considering that only two states provide for such legal figure, and notwithstanding the fact that the General Law establishes a time limit for states to introduce this legal precept in their civil legislation, it will depend largely on the political will of state congresses.

In words of Verástegui González, the declaration of absence would allow the victim, in the event of being found alive, to find similar circumstances with regards to, among other issues, his or her family, job, and property as they were

127 Concluding observations Mexico, supra note 12, 43. The Working Group also recommended "the declaration of absence following the forced disappearance should be allowed." Report of the Working Group-2011, supra note 12, 86.

128 General Law, Arts. 142 to 144. It is worth noting that at the time of this work, only the states of Coahuila and Querétaro provide for this legal figure in their legal framework. Decreto 490, Ley para la Declaración de Ausencia por Desaparición de Personas del Estado de Coahuila de Zaragoza, May 20, 2014 (Méx.), and Concluding observations Mexico, supra note 12, 42. The Ninth Transitory Article of the General Law establishes a period of 180 days for the National Congress and State Congresses to legislate on the matter once the law is in force.

129 See General Law, Arts. 147 to 148.

130 Id. at Arts. 145 and 146. 
before his or her disappearance. Verástegui González states that the declaration of absence aims to "freeze" the rights and duties of the victim until he or she is found alive, thus materializing the presumption of life. ${ }^{131}$

Besides, the General Law's express reference to Inter-American Court judgments on matters of reparations, it broadens the scope of possibilities and options for the next of kin of the disappeared or missing person to have a way to be redressed for the violations committed against them and their loved ones, if it is possible to speak of reparation in the case of such an abhorrent crime.

\section{Gonclusion}

The enactment of the General Law is only the first step to prevent the crime of forced disappearances and to investigate, prosecute, and, if applicable, punish those responsible for committing the crime, and grant adequate and full reparation for the victims and their next of kin.

As a legislative measure, the General Law is, to a large extent, in accordance with international human rights standards on the issue. However, the partial compliance with the ruling in the Radilla Pacheco case with regards to military jurisdiction, as well as a lack of clear laws on the responsibility of hierarchal superiors as the masterminds of the crime of forced disappearance, suggest that future amendments to either the General Law or criminal laws are required in order to comply with international standards.

Furthermore, even when the General Law constitutes a significant first step by establishing several different institutions, registries, procedures, and mechanisms that involve not only the federal jurisdiction, but state and municipality jurisdictions as well, enormous political will is needed to provide these new institutions with enough resources (material and human) to achieve the purpose aimed by the law. Political will is also needed to establish the coordination between different authorities and institutions, as stipulated in the General Law as a requirement for its effective implementation.

Along this line, during the enactment ceremony of the General Law, Jan Jařab, a representative of the United Nations Office of the High Commissioner for Human Rights in Mexico, recalled that "it was an international organization $^{132}$ the first to recommend the adoption of a general law on forced

131 Jorge Verástegui González, La personalidad jurídica en la desaparición forzada, CNDH 45 (2016), available at https://archivos.juridicas.unam.mx/www/bjv/libros/10/4852/11.pdf.

132 Even when the representative did not mention which organization had issued the recommendation, it can be inferred that it was the Working Group on Forced or Involuntary Disappearances, which, after visiting Mexico from March 18 to 31, 2011, recommended "that the offence of forced disappearance should be included in the criminal codes of all states and that a comprehensive law on forced or involuntary disappearances should be adopted without delay. Under this general law forced disappearance should be defined as an autonomous offence." Report of the Working Group-2011, supra note 12, Summary and 86. 
Esta revista forma parte del acervo de la Biblioteca Jurídica Virtual del Instituto de Investigaciones Jurídicas de la UNAM http://www juridicas unam mx/

https://biblio.juridicas.unam.mx/bjv

https://revistas.juridicas.unam.mx/

DOI: http://dx.doi.org/10.22201/iij.24485306e.2019.2.13641

disappearances after an official visit to Mexico in 2011" and that even though it is not the solution, it is part of one if implemented effectively. He pointed out that the General Law aspires to overcome existing impunity and revictimization patterns and that it adopts the highest international human rights standards. ${ }^{133}$

Also, as the "Movimiento por Nuestros Desaparecidos en México" 134 remarked, it is imperative that the establishment of the institutions created by the General Law is followed by the necessary budget, the participation of the victim's family members, and other legislative amendments. ${ }^{135}$ The Nineteenth Transitory Article provides that the Federal Administration and state legislatures must establish the necessary budget for the implementation of the General Law. ${ }^{136}$ In the 2018 Expenses Budget, the amount of $\$ 186,354,100$ (approximately 9,900,000 US dollars) was designated for the implementation of the General Law and $\$ 282,592,800$ (approximately 15,023,859 US dollars) was earmarked as a subsidy for states to implement the General Law. ${ }^{137}$

The General Law stipulates different terms under which the institutions created shall be established and for the correspondent authorities to make the necessary amendments to their legal framework, to issue guidelines, rules, programs, and protocols, and to take any necessary measures in order to adapt their activities to the regulations established in the General Law. ${ }^{138}$

At this time, it is too soon to determine whether the General Law will, in fact, substantively contribute to eliminating or lowering the high levels of impunity surrounding the crime of forced disappearance and the outrageous number of missing or disappeared persons in Mexico. As a legislative measure, it corresponds to the most international human rights standards in

133 Jan Jařab also pointed at the limitations of the law in matters like search procedures and the superior hierarchical responsibility. Palabras de Fan Farab para la Promulgación de la ley general de desaparición, Oficina del Alto Comisionado de las Naciones Unidas en MéXico

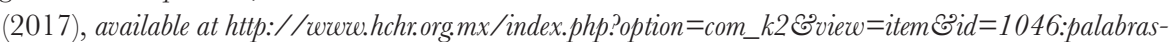
de-jan-jarab-para-la-promulgacion-de-la-ley-general-de-desaparicion EItemid $=395$.

134 Movimiento por Nuestros Desaparecidos en México is a social movement made up of more than 35 groups of disappeared persons' relatives, and almost 40 organizations that work together to overcome the situation of forced disappearances in Mexico. See Movimiento por Nuestros Desaparecidos en México, "Nosotros", website, available at http://sinlasfamiliasno. org/nosotros/.

135 Aprobación de la ley de desaparición es el primer paso, las familias exigimos una implementación eficaz y nuestra participación durante todo el proceso, MovimiEnTO POR Nuestros Desaparecidos en MéXico (2017) available at http://sinlasfamiliasno.org/aprobacion-laley-desaparicion-primer-paso-las-familias-del-movimiento-desaparecidos-en-mexico-exigimos-una-implementacion-eficaz-nuestra-participacion-proc/.

136 See General Law, Nineteenth Transitory Article.

137 Presupuesto de Egresos de la Federación para el Ejercicio Fiscal 2018, Diario Oficial de la Federación [D.O.] November 29, 2017 (Mex.), at Sixth Transitory Article.

138 See General Law, Transitory Articles Third to Eight, Eleventh to Sixteenth and Twentieth to Twenty-First. 
matters of forced disappearances. However, it is reiterated, its effectiveness will depend largely on the political will of the federal and state authorities in charge of implementing, establishing, training, and coordinating the different operators and institutions needed for the proper implementation of the General Law at all government levels.

The situation of forced disappearance has reached a critical point in recent years where neither the government nor society as a whole can deny its impact. It is incontrovertible that the enactment of the General Law, as a legislative measure aimed to ensure and fulfil the rights of justice, truth and reparation of the victims of forced disappearance and their next of kin is an action without precedent, thanks primarily, to the lifelong fight of those whose lives have placed them in one of the worst situations a person can ever find themselves, not knowing the fate of their loved ones. 